\title{
The Problems of Gifted Children and Solution Suggestions within the Context of Parents' Standpoint*
}

\section{Research Article}

\section{Sahin ORUC', Sibel CAGIR ${ }^{2}$}

${ }^{1}$ Yildiz Technical University, Faculty of Education, Department of Turkish and Social Studies, Turkey, ORCID: 0000-0001-8666-3654

${ }^{2} Y$ ildiz Technical University, Institute of Social Sciences, Department of Turkish and Social Studies, Turkey, ORCID: 0000-0002-8312-1152

To cite this article: Oruc, S., \& Cagir, S. (2021). The problems of gifted children and solution suggestions within the context of parents' standpoint, International Online Journal of Educational Sciences, 13(2), 461-477.

\begin{tabular}{l} 
ARTICLE INF \\
\hline Article History: \\
Received: 04.06.2020 \\
Available online: \\
23.04.2021
\end{tabular}

23.04.2021

\begin{abstract}
ABSTRA
Inspite of the all special abilities of being gifted, it could also confront the individuals and their families with some negative situations or problems. Determining these problems is important in terms of both getting to know these individuals and all further applications and studies to be done. These problems could be learned from families, with whom children spend most of their life together in almost every period of their lives. With this idea, it was aimed in the study to determine what problems their families experience with gifted individuals and what solutions they proposed to these problems. In this qualitative study, the phenomenology pattern was used. The sample group of the study consists of 16 parents with gifted children. The data were obtained through a semi-structured interview form prepared by the researcher. The data obtained were analyzed by content analysis. The data were given by creating themes and sub-themes directly with quotations from the participants' opinions. As a result of the research, the sub-themes of these themes were created by giving the parents' expressions about the problems faced by the children in 10 themes and solution suggestions in 11 themes. According to parents, gifted children experience problems arising from private institutions, educators and administrators, families, curriculum and educational environments, children themselves, assessments, environmental factors, problems with the Science and Art Center (BİLSEM), peer communication and economic situations. Parents offered different solutions for these problems. Studies could be carried out for these detected problems. In the further application for gifted individuals, it is recommended that parents' views are also consulted.
\end{abstract}

C 2021 IOJES. All rights reserved

Keywords:

Superior Ability, Problems Faced by Parents and Gifted Children, Solution Suggestions

\footnotetext{
"This article iswritten by expanding it from the oral presentation presented in ERPA.

${ }^{1}$ Corresponding author's address: Y1ldiz Technical University, Institute of Social Sciences, Department of Turkish and Social Studies, Turkey Telephone: +905314041757

e-mail: sahinoruc44@hotmail.com, cagirsibel@gmail.com

DOI: https://doi.org/10.15345/iojes.2021.02.009
} 


\section{Introduction}

There have always been turning points in both humans' and countries' histories. These milestones have manifested themselves in the form of discovering, uncovering or creating something. These milestones in human history are generally the product of a genius. Geniuses like Fatih Sultan Mehmet (Mehmet the Conquerer) or like Einstein set an example for this with their intelligence guiding the fate of humanity. As in the past and today, these important milestones would be the product of superior intelligence. For this reason, it is very important for the gifted individuals with this superior intelligence to receive the necessary attention and importance in every period of life.

It would not be wrong to think of gifted individuals as a gem. All people should know the processing of these gems. Işık and Güneş (2017) compare gifted individuals to a rare gem in nature. They state that these individuals, which attracted attention, are gems for humanity. Therefore, they emphasize the importance of these ores to be cared as they deserve and to be benefited from these abilities in the areas needed in the world they live in.

It should not be forgotten that every new step taken in civilization is a product of creativity (Davaşligil, 1990: 22). The discovery of gifted individuals is extremely important. However, another important issue as well as their discovery is the process following their being identified as gifted. Gifted individuals need special education, special attention and special conditions that would reveal their performance. It is important to shape the productivity of these individuals positively for the advancement of the civilization. Otherwise, these abilities are likely to be blunted or they might have no positive contribution to humanity. For this reason, it is an important issue to identify the problems that gifted individuals encounter throughout their lives. It is the greatest expectation to make plans in line with the detected problems.

The main responsibility of raising a child from the beginning of the childhood belongs to the family. In the process until the school years of the children, the major responsibility belongs to the families. Especially, families with gifted children have more and higherlevel responsibilities. Parents of children with developmental characteristics different from their peers face with their children's struggle against prejudices during school periods. For children who have the right to receive special education from the age of 4 , the state's diagnostic studies begin before this age. When studies and applications for gifted children are examined in our country, it is seen that these studies are limited. (Oruç, Ateş, Çağır, 2019: 255).

In the studies, on the education of gifted individuals in our country, it is seen that families who are directly related to these individuals' education and who witness, face or experience these problems together with children are not taken into consideration. The needs of every gifted child at the first moment of their birth and in their later lives differ from their normally-developing peers. Attention should be paid so as not to leave their families alone in the education process of these children. Due to this necessity, education of families having great role in determining gifted individuals, directing them in line with their interests and abilities and supporting their development in these areas is also important (Karakuş, 2010:128).

Being gifted is not only the existence of superior general intelligence potential in the individual. Therefore, it is preferred to use gifted or talented concepts instead of superior minded. This situation could be shown as intelligence has a labeling impact on the individual (Özbay, 2013: 265). In this sense, the preference of the concept as gifted is defined in the preliminary report published in the 1st Special Education Commission organized by the Ministry of National Education (MoNE) (1991) as "superior mind" and "superior special ability" have all been gathered under the title of "giftedness", and gifted people have been identified by experts as high-performing people in terms of their general and/or special talents compared to their peers."(MEB, 2007) 
It is possible to come across many definitions about gifted or talented individuals. In this sense, Clark (1997) identifies individuals who have distinguished abilities and children with high level of qualifications as gifted. According to Hallahan and Kauffman (1994), another definition has been explained as gifted individuals are those who reveal superior performances in intelligence, productivity, art, leadership capacities or in special academic fields, and those who are to be provided required services and activities different from normal activities by educational institutions in order to develop all of their existing capacities in these areas.

"Individual's having the superiority depends not only on the innate abilities but also on the appropriate education, environment and elements of personality" (Davaşligil: 1990: 19). In this sense, "The family has an important place in the educational future of the child than any institution" (Çăglar, 1990: 29). For this reason, it is important to carry out studies to identify the problems experienced by individuals and to eliminate these problems in order to ensure that these individuals receive education in appropriate environmental conditions. Therefore, this study which tries to identify the problems experienced by gifted children through families, is of upmost importance.

\section{Method}

\section{Model}

In this study, the phenomenology pattern, one of the qualitative research models, is utilized. Phenomenology approach is the examination of the cases that we are aware of but do not have an in-depth and detailed understanding of (Yıldırım \& Şimşek, 2016: 69). Phenomenology is one of the qualitative research patterns with its own focus and methodological strategies. Phenomenological research is about the underlying structure of a fact or a phenomenon (Merriam, 2013).

\section{Sample Group}

In phenomenology studies, data sources consist of individuals or groups that experience the phenomenon focused in the study and that can reflect or transfer this phenomenon (Yıldırım \& Şimşek, 2016). For this purpose, the sample group of the study involves the voluntary participation of parents with gifted children. The study group is determined by homogeneous sampling among the purposeful sampling methods. P1, P2... P16 codes are given to the participants. Purposeful sampling is a sampling developed within the qualitative research tradition. Purposeful sampling gives an opportunity to study on situations that are considered to have rich knowledge (Plato, cited in 1987: Yıldırım \& Şimşek, 2016: 118).

Table 1. Personal Information for Parents in the Study Group

\begin{tabular}{lll}
\hline Distribution by Parents' Gender & $f$ & $\mathbf{\%}$ \\
\hline Female & 10 & 1.6 \\
Male & 6 & 0.96 \\
\hline Total & 16 & 100 \\
\hline
\end{tabular}

As given in Table 1, at total of 16 parents of gifted children, 10 females and 6 males, participate in the study.

\section{Data Collection Tool}

The main data collection tools in phenomenology studies are interview forms (Yıldırım \& Şimşek, 2016: 71). In this phenomenology study, a semi-structured interview form with two open-ended questions is designed by the researchers as a data collection tool suitable for the purpose of the study. Questions in the interview form follow as such:

1. What are the Problems Your Gifted Children Face?

2. What are Your Solution Suggestions for the Problems Faced by Your Gifted Children? 


\section{Analysis of the Data}

Phenomenology studies aim to reveal analysis of the data, experiences and meanings. In the content analysis carried out in this direction, there is an effort to conceptualize the data and to create themes that could meet the reached phenomenon. In these studies, the results are conveyed in a descriptive narration and direct quotations are frequently made from the obtained data. In this context, the emerging theme and the reached findings are interpreted by explaining (Yıldırım \& Şimşek, 2016: 72).

The common and similar answers given by the parents to the questions in the interview form are presented in the form of themes and sub-themes. These tables are created separately for each question. Multidimensional answers given by parents to open-ended questions are given as sub-themes within the themes and main theme expansion is tried to be provided. In addition, the themes created to ensure the reliability of the study are created by taking expert opinion. Also, quotations from the parents' views are frequently tried to be cited. The reliability of study is tried to be ensured by coding the participants as P1, P2 ...... P16 and presenting their opinions.

\section{Findings and Comments}

In this part of the study, the themes and sub-themes created in line with the content analysis of the answers obtained from the open-ended interview form applied to the parents of gifted children are presented in tables. Quotations are interpreted in accordance with the interview forms by giving quotations from the parents' opinions frequently.

Table 2. The Themes and Sub-Themes Being Formed from the Answers Given to the Question: "What are the problems that the gifted children face?"

\begin{tabular}{|c|c|c|c|}
\hline Question & Theme & $f$ & Sub-themes \\
\hline \multirow[t]{4}{*}{$\begin{array}{l}\text { What are the } \\
\text { problems that } \\
\text { the gifted } \\
\text { children face? }\end{array}$} & 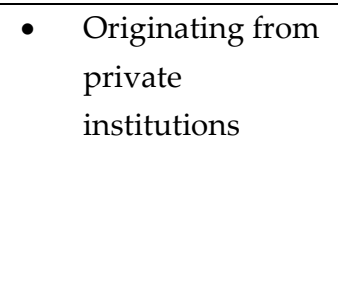 & 16 & $\begin{array}{ll}\text { - } & \text { Economically unaffordable } \\
\text { - } & \text { Institutions prevailing profit } \\
\text { - } & \text { Problems of accessibility of the institutions } \\
\text { - } & \text { Fixed workshops in institutions } \\
\text { - Institutions having no compliance with the } & \text { state }\end{array}$ \\
\hline & 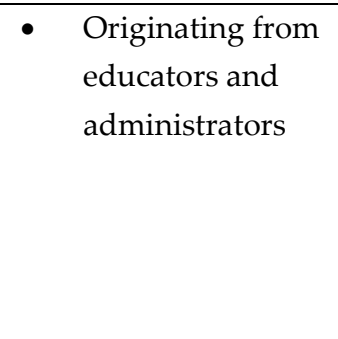 & 15 & $\begin{array}{l}\text { - The lack of having enough knowledge } \\
\text { - The lack of qualified teachers } \\
\text { - } \quad \text { Failure to guide the students in line with their } \\
\text { interests, abilities and potential } \\
\text { - Expectation of the child to be successful in all } \\
\text { areas } \\
\text { - } \quad \text { Lack of studies on peer communications }\end{array}$ \\
\hline & $\begin{array}{l}\text { Originating from } \\
\text { the families }\end{array}$ & 15 & $\begin{array}{l}\text { - } \\
\text { - } \text { Fducators do not guide the families } \\
\text { - } \quad \text { Families cannot quide the children } \\
\text { - } \text { The absence of the applications and awareness } \\
\text { raising endeavours } \\
\text { - Families are not included in the education } \\
\text { - } \quad \text { processes } \\
\text { - } \quad \text { Being passive against the children }\end{array}$ \\
\hline & $\begin{array}{l}\text { - } \begin{array}{l}\text { Originating from } \\
\text { the curriculum } \\
\text { and educational } \\
\text { environments }\end{array}\end{array}$ & 14 & $\begin{array}{l}\text { - } \quad \text { Inadequacy in project-making } \\
\text { - } \quad \text { The problems of activities } \\
\text { - } \quad \text { Students cannot reveal their performances }\end{array}$ \\
\hline
\end{tabular}


- Students already know the subjects in the curriculum

- Curriculums are based on memorizing in practice

- Educational applications cannot go beyond theory

\begin{tabular}{|c|c|c|c|}
\hline & $\begin{array}{l}\text { Originating from } \\
\text { the children's } \\
\text { themselves }\end{array}$ & 13 & $\begin{array}{l}\text { - Their permanent demand of resting } \\
\text { - They demand logical explanations for } \\
\text { everything } \\
\text { - } \quad \text { They question everything } \\
\text { - Not being satisfied with the subjects their } \\
\text { - } \quad \text { Parents have no idea about } \\
\text { - The children are either introvert or they cannot } \\
\text { - } \quad \text { children regard their families as insufficient }\end{array}$ \\
\hline & $\begin{array}{l}\text { Originating from } \\
\text { the evaluation }\end{array}$ & 10 & $\begin{array}{l}\text { - Children are evaluated within the framework } \\
\text { of the curriculum } \\
\text { - Their talents and abilities are ignored } \\
\text { - The existence of theoretical evaluation } \\
\text { - The regression in their achievement areas } \\
\text { - The performance and creativity are ignored }\end{array}$ \\
\hline$\bullet$ & $\begin{array}{l}\text { Originating from } \\
\text { the environment. }\end{array}$ & 10 & $\begin{array}{l}\text { - Children face psychological problems } \\
\text { resulting from the high expectations, anxiety } \\
\text { and feeling insufficient/unsuccessful }\end{array}$ \\
\hline & $\begin{array}{l}\text { Problems } \\
\text { regarding BİLSEM }\end{array}$ & 9 & 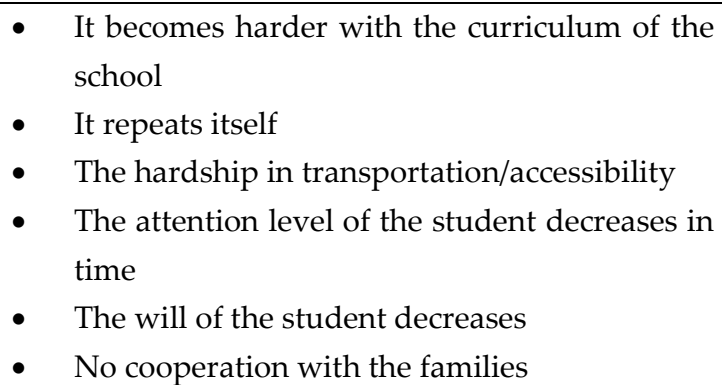 \\
\hline & $\begin{array}{l}\text { Problems about } \\
\text { peer } \\
\text { communication }\end{array}$ & 9 & $\begin{array}{l}\text { - } \quad \text { Being labelled as gifted } \\
\text { - } \quad \text { Expectation of success in every field } \\
\text { - } \text { Being aware of the superiority compared to the } \\
\text { - } \quad \text { Coners } \\
\text { - } \quad \text { Exclusion } \\
\text { - } \quad \text { Being alone }\end{array}$ \\
\hline & $\begin{array}{l}\text { Economic } \\
\text { Problems }\end{array}$ & 7 & $\begin{array}{l}\text { - } \\
\text { fot being able to provide the required budget } \\
\text { - } \\
\text { - Not being able to provide opportunities } \\
\text { - } \\
\text { children being able to meet the expectations of the } \\
\text { Blocking their creativity }\end{array}$ \\
\hline
\end{tabular}

As could be seen in Table 2, the problems experienced by parents and children are given in themes of "Problems originating from private institutions, originating from educators and administrators, originating from the families, originating from the curriculum and educational environments, originating from the 
children's themselves, originating from the evaluation, originating from the environment, problems regarding BİLSEM, problems about peer communication, economic problems".

The themes in the table are given in order of frequency. Accordingly, the most recurring themes by the participants are as follows: "Problems originating from private institutions, originating from educators and administrators, originating from the families, originating from the curriculum and educational environments, originating from the children's themselves, originating from the evaluation, originating from the environment, problems regarding BILSEM, problems about peer communication, economic problems".

1. Problems originating from private institutions: Parents believe that there should be alternative educational institutions for the education of gifted children, or institutions that could support their development with extra activities and studies other than schools. Parents, who think that children should receive talent-based education, state that their children also want this. However, they state that these are statesupported multi-class institutions, and therefore they lean to private institutions. It has been determined that this situation causes economic problems for parents. Apart from economic ones, other problems experienced by children in these institutions are also stated. They express that children are bored with similar and fixed workshops in these institutions. Also they state that there are a few institutions and this causes a transportation problem. It is indicated that this causes children to get bored of the institution or not to want to go there. In addition, it is also determined that this emerges economic problems for them and parents think these institutions aim at benefits. Among the problems experienced by children, it is determined that they face problems related to the private institutions.

2. Problems originating from educators and administrators: They state that the problems gifted face are experienced since the educators do not have enough knowledge about gifted children, they do not provide adequate guidance for them, they expect giftedness from their students, and they do not do any study for the communication of children with their peers. Pointing out the lack of trained teachers for gifted children, the parents state that this situation causes major problems for their children. They also state that the administrators do not have knowledge about gifted children, they could not perform any practice and they do not have any communication with the families. In addition, it has been determined that children have problems in peer communication, teachers do not try to work on this subject, and they expect teachers to play a positive role in peer communication.

P1: Unfortunately, the knowledge and culture of our country about gifted individuals and their problems are very weak. However, academics in some faculties and teachers who have been passionate about this work do this by their own efforts, but they are not able to reach enough children.

3. Problems originating from families: Parents state that they are inadequate towards their children, especially in areas in which their children's interests or abilities perform superior performance, they do not know which way to take in guiding their children and they state that the children are left unanswered with the questions they constantly ask. It is found that this situation causes children to be dissatisfied with their parents and that they think they have a lack of trust against their parents. Parents regard the reason for these problems as that they do not have education for their children and they are not informed about their children's educational process.

4. Problems originating from curriculum and education environments: Parents state that their gifted children experience deficiencies and problems arising from the curriculum and program. They express that the curriculum remains in theory and is not effective in practice. They state that the current curriculum could not reveal children's interests and abilities, and does not give them the chance to perform projects related to performance, effectiveness and especially children's interests. They utter that their children already knew the topics taught in schools and that they were, thus, bored with the school environment. It has been determined 
that there is no additional regulation for gifted students in the educational environment, which also creates negativity since their children could not have an area to realize themselves.

In addition, parents are of the opinion that existing education models, practices or plans for gifted children remain only in theory.

5. Problems originating from children themselves: Parents state that gifted children have a constant desire to make people listen to them, and this creates the idea that their opinions are not considered important after a while. Gifted children question all subjects they encounter, but not getting sufficient answers leads children not to be satisfied.

In this circumstances, the child considers his/her family as insufficient and becomes introvert, and the families think that it is originating from children themselves as well as the environmental factors.

6. Problems originating from evaluations: As it could be added to the problems arising from the curriculum, this theme has been created separately since $100 \%$ of the 16 participants express that they are negatively affected by their children's assessments. All of the parents utter that the evaluations made through the exams cause the failure of their students and this situation leads the childdren to have negative emotions. They also state that the evaluations are not on the areas where children show superior performance or on their skills and abilities and evaluations related to memorizing still continue.

7. Problems originating from environmental factors: Parents express that children are negatively affected due to environmental pressure, expectation and labeling. Children might experience psychological problems because of the anxiety, inadequacy and failure feelings with the awareness of high expectations by the society they are involved. It is also among the expressions of parents that the perception of the environment that a gifted individual could do anything causes the child to be excluded by her/his peers.

8. Problems originating from Science and Art Center (BILLSEM): Parents with the children attending the science and art centers state that they have problems caused by Science and Art Center (BILLSEM). Among these problems, students are exposed to an intensive program due to the fact that the BİLSEM program is simultaneous with the school time. They state that workshops in these institutions, which are repeatitive and without changes, reduce children's interest. It has been determined that the low level of technological workshops in these institutions reduces the desire of children to go to there. On the other hand, parents utter that there are transportation difficulties due to the low number of the institutions, and also there is no cooperation with families.

9. Problems about peer communication: In this theme, it is resulted that children generally experience problems arising from peer communication. However, it is not possible to obtain a distinction from the data obtained from the parents whether the children experience problems from their peers in the state or private school or from their gifted peers in BİLSEM. Parents state that labeling their children as gifted causes high expectations from them. In addition, they think that their children have problems in communicating and consider the area or areas where they have superior abilities are more important than all other areas, and that their children see their peers inadequate while their peers expect them to be superior in all areas. As a result, they express that their children face the problem of being alone or being excluded.

10. Economic Problems: Parents who state that their children's interests and abilities require a certain economic level, express that if they could not provide it for them, children's talent areas are blunted, any opportunity could not be created for them, they could not meet their expectations and it would prevent children from revealing their productivity. Economic conditions for parents have a great impact on the education and life of the gifted children in our country. 
According to the table and parents' opinions, it could be said that there are some differences and similarities between the problems experienced by children. Themes emerging according to the table show that in general children experience problems related to education and social and economic reasons.

Table 3. The Themes and Sub-Themes Formed from the Answers Given to the Question: "What Are Your Solution Suggestions Regarding the Problems Gifted Children Face?"

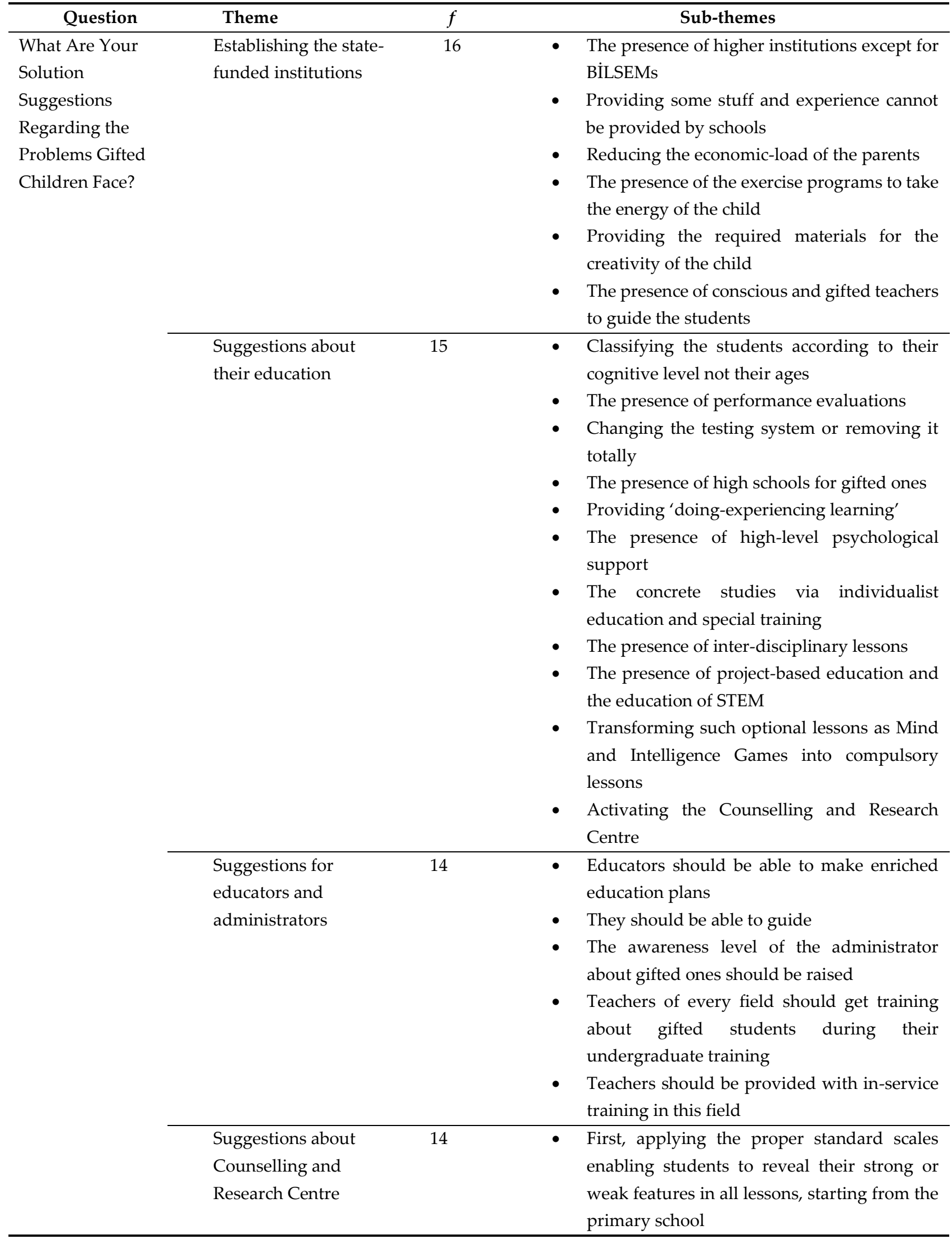


- Counselling and Research Centre should follow all of the students

- Counselling and Research Centre should increase their cooperation with the counselling teachers at schools

- Counselling teachers should be good observers and guides

- Students should be detected at early ages

\begin{tabular}{|c|c|c|}
\hline $\begin{array}{l}\text { The endeavours for } \\
\text { employment } \\
\text { opportunities }\end{array}$ & 14 & $\begin{array}{l}\text { - The child should study in the fields where } \\
\text { s/he can show his/her success and talent } \\
\text { - } \quad \text { Removing the concerns of the students about } \\
\text { future } \\
\text { - } \quad \text { Removing the concerns of the families about } \\
\text { future } \\
\text { - Blocking the brain drain }\end{array}$ \\
\hline The state policies & 13 & $\begin{array}{l}\text { - The state should develop policies directly } \\
\text { covering today and future of the gifted ones } \\
\text { - The cooperation of the state, families, } \\
\text { academicians and educators } \\
\text { - The presence of schools like ARGEM } \\
\text { (Research Development Centre) and } \\
\text { TÜZDER (All Gifted Ones association) in all } \\
\text { cities } \\
\text { - Identifying, Description, Training, } \\
\text { Observation should include employment } \\
\text { The presence of research-development } \\
\text { support and logistic services } \\
\text { Increasing the numbers of the try it-do it } \\
\text { workshops }\end{array}$ \\
\hline $\begin{array}{l}\text { Research Centres at } \\
\text { Universities }\end{array}$ & 13 & $\begin{array}{l}\text { - There should be departments doing research } \\
\text { on gifted individuals } \\
\text { - Teacher candidates should get training for } \\
\text { gifted students } \\
\text { - Giving lectures to families to raise their } \\
\text { awareness levels } \\
\text { - Supporting the children to develop } \\
\text { themselves in these centres according to their } \\
\text { abilities } \\
\text { - Conducting international studies }\end{array}$ \\
\hline $\begin{array}{l}\text { Adequate } \\
\text { educational } \\
\text { environments }\end{array}$ & 13 & 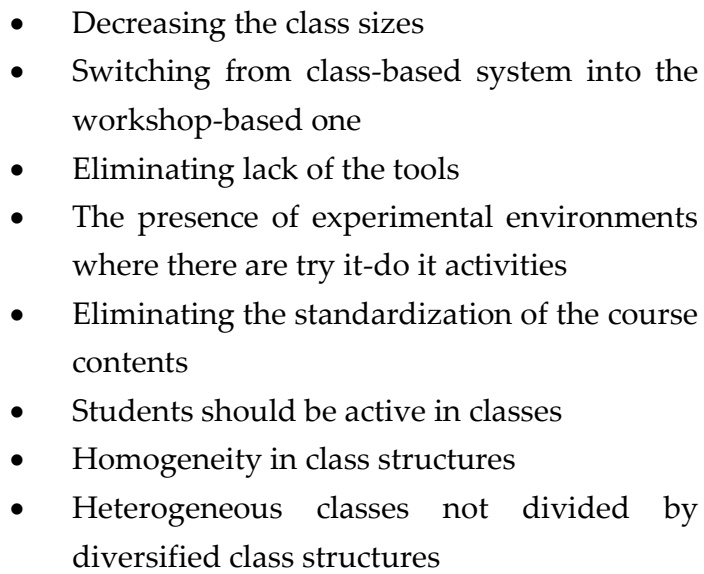 \\
\hline
\end{tabular}


- The special classes and coherent classes

- Environments to improve the imagination of the child

- The environments to support the physical and social development

\begin{tabular}{|c|c|c|}
\hline $\begin{array}{l}\text { Evaluations } \\
\text { according to the } \\
\text { performances and } \\
\text { talent areas }\end{array}$ & 12 & $\begin{array}{l}\text { - The interactive evaluations including the } \\
\text { fields the child is superior at } \\
\text { - } \quad \text { Not evaluating the success via written exams } \\
\text { - } \quad \text { Not evaluating with a score-based grading } \\
\text { system } \\
\text { - There should be project-based evaluations }\end{array}$ \\
\hline $\begin{array}{l}\text { Suggestions } \\
\text { BİLSEM }\end{array}$ & 10 & $\begin{array}{l}\text { - Innovations to be made } \\
\text { - The need of cooperation with the family } \\
\text { - The problems resulting from the extensive } \\
\text { work-load from the school hours should be } \\
\text { solved } \\
\text { - The educators in BİLSEM should consist of } \\
\text { the teachers cooperating with the universities } \\
\text { in projects and field studies } \\
\text { - Studies for the summer schools should be } \\
\text { made } \\
\text { Academicians should be included in this } \\
\text { institutions }\end{array}$ \\
\hline $\begin{array}{l}\text { Suggestions for the } \\
\text { programme }\end{array}$ & 10 & $\begin{array}{l}\text { - There should be a programme for gifted ones } \\
\text { - } \quad \text { This programme should be included in the } \\
\text { curriculum } \\
\text { - The programme should be aimed at multiple- } \\
\text { intelligence theory } \\
\text { - BEP (Individualised Education Programme) } \\
\text { should be prepared }\end{array}$ \\
\hline
\end{tabular}

Parents' suggestions for solutions to children's problems are similar or directly the same. In this sense, a common theme is created for solution suggestions that are similar, and are given in 11 themes. As could be seen in Table 3, the solutions offered by the parents are given sub-themes within the themes and their demands are conveyed.

As could be seen in Table 3, parents make suggestions about "Establishing the state-funded institutions, Suggestions about their education, Suggestions for educators and managers, Suggestions about Counselling and Research Centre, The endeavours for employment opportunities, The state policies, Research Centres at Universities, Adequate educational environments, Evaluations according to the performances and talent areas and Suggestions for BILSEM, and Suggestions for the programme". Similar to the case in the problems, solution suggestions are related more about the education and future of children.

The themes in the table are given in order of frequency. Accordingly, the most recurring themes by the participants are as follows: "Establishing the state-funded institutions, Suggestions about their education, Suggestions for educators and managers, Suggestions about Counselling and Research Centre, The endeavours for employment opportunities, The state policies, Research Centres at Universities, Adequate educational environments, Evaluations according to the performances and talent areas and Suggestions for BİLSEM, and Suggestions for the programme". 
1. Establishing the state-funded institutions: According to the parents, education of the gifted children in schools is not sufficient. Besides, they think that the number of the similar institutions such as BILSEM should be increased: however, they demand that these institutions should also be state-funded. Thus, in their opinion, the problem of not sending their children to private institutions for economic reasons would disappear. They suggest that there should be enriched educational environments and well-trained teachers for gifted children in these institutions, and there should be exercise programs that would make the students active and help them get rid of their energies.

2. Suggestions about their education: This theme includes solution suggestions that parents think that problems experienced by gifted children about any kind of their education would be resolved. Accordingly, parents recommend classes should be created according to the children's cognitive levels, not their ages. They suggest that there should be performance evaluations, the exam system should change or exams should not be conducted, students should be provided with high level psychological support, and individual education and special education should provide concrete study in this area. In addition, they recommend making projects and products for children's interests, giving interdisciplinary courses, providing project-based training and STEM training would be helpful.

Parents who want to have obligatory courses such as robotic coding and optional Mind and Intelligence Games also recommend to have technology-oriented workshops, such as model aircraft designing. They suggest that Guidance and Research Centers (RAMs) should be active in other areas as well as detecting their children at an early age. A parent's opinion is given below as an example.

P1: Gifted individuals who learn faster than their peers need special education. For this reason, in a very serious subject such as the education of these children, an inspiration like Enderun-type special education is needed. Similarly, the staff who are specifically selected and trained for the raising of these children, totally expert in their fields, patient, constantly self-renewing, constantly reading, constantly searching, understanding the children's spirit, tolerant, positive, and using the technologies of the recent era are needed.

3. Suggestions for educators and administrators: Parents think that teachers of every field, specifically the ones to educate the gifted students, should get training about gifted students during their undergraduate training. They advise that the teachers should make an enriched education plan, being aware of the fact that these special students are also in their classrooms during the education process. They recommend that teachers be able to guide the children towards the areas in which they are successful. Parents think that the administrative staff should be informed about gifted individuals. They suggest that administrations and teachers should cooperate with families. A sample view from the one of the parents is presented below:

P16: The child should be guided according to whatever interest and ability the child has. Painting, music, writing, astronomy, robotics, crafts, language learning, physical education, sports etc.

4. Suggestions about Counselling and Research Centre: They propose, first, applying the proper standard scales enabling students to reveal their strong or weak features in all lessons, starting from the primary school. They suggest that Counselling and Research Centre should follow all of the students; Counselling and Research Centre should increase their cooperation with the counselling teachers at schools, and that there should be endeavours for Counselling teachers to be good observers and guides. A sample view from one of the parents is presented below:

P9: First of all, these individuals should be identified and diagnosed by powerful counselling departments at a young age. Diagnosed individuals should be supported and assisted to improve their biological, psychological and social development in the healthiest way possible. 
5. The state policies: They suggest that the number of the studies for gifted individuals should be increased and they should be state-funded. They propose that the state should develop policies directly covering today and future of the gifted ones. They also indicate that the state should be in cooperation with families, academicians and educators in each study or research that it conducts.

They propose that with the support of the state, schools like ARGEM (Research Development Centre) and TÜZDER (All Gifted Ones association) should be founded in all cities. They suggest policies to be conducted in such areas as Identifying, Description, Training, Observation, and conferences regarding these subjects, as well as research -development support, logistic services and try it-do it workshops. A sample view from one of the parents is presented below:

P9: Providing employment to the individuals who have completed their education and training should be made a state policy.

6. The studies for employment opportunities: Parents who are worried about their children's future have made suggestions for their future as well as suggestions for the problems experienced today. These suggestions are given in the form of employment studies, apart from the theme of the state policies. Development opportunities should be provided starting from today in a field where the child can show his/her success and superior ability. They recommend that starting the employment studies today would reduce their children's anxiety for future. Thus, they expressed that the family's worries for future would be eliminated, too.

They state that it is necessary to create opportunities in employment in which the talented people who would lay the foundations for the future, could serve the whole world starting from our country in the future. Thus, it is thought that brain drain can be prevented.

7. Research Centres at Universities: Parents recommend that there should be departments doing research on gifted individuals and that teacher candidates should get training for gifted students in these departments. They offer that these departments give lectures to families to raise their awareness levels. They express that supporting the children to develop themselves in these centres according to their abilities in their departments would affect the development of these children positively. They indicate that international studies should be conducted and the children should be involved. The academicians should cooperate with the adult educators for the gifted children.

8. Adequate educational environments: Parents indicate that being in crowded classrooms has negative impact on the children and for this reason, the class sizes should be decreased. They suggest to switch from class-based system into workshop-based one as well as the presence of experimental environments where there are try it-do it activities. They suggest that eliminating the standardization of the course contents and eliminating the lack of the tools are necessary and that the classes should be taught actively. There are parents, who defend homogeneity in class structures and special and coherent classes, as well as those who demand heterogeneous classes not divided by diversified class structures. They proposed that environments to improve the imagination of the child and the environments to support the physical and social development of the child are necessary. A sample view from one of the parents is presented below.

P3: Unfortunately, the physical conditions and structures of the schools as well as teaching environments are not suitable for the gifted students. If the physical conditions are adequate, two classes should be determined as special at the schools such as science class, art class or space class. These classes should be equipped with the required materials and experts should be asked for help while forming these classes.

9. Evaluations according to the performances and talent areas: Parents who think that the evaluations in schools lead to the idea of failure in the student and that there is no assessment about their students' abilities, 
suggest interactive evaluations which involve the fields the child is superior at. Parents think that children's success should not be measured with written exams or a score-based assessment. They indicate that projectbased evaluations would reveal or develop the creativity of the children.

10. Suggestions for BİLSEM: Parents regard BİLSEMs as great opportunities for their children. Yet, the problems deriving from this institution are given above. Thus, parents demand innovations and various workshops in BİLSEMS. They mention the need of cooperation with the family. They allege that BILSEMs should solve the problems resulting from the extensive work-load from the school hours and that the educators in BILLSEMs should consist of the teachers cooperating with the universities in projects and field studies. They suggest that studies for the summer schools should be made and academicians should be involved in these institutions.

11. Suggestions for the programme: Parents propose that there should be a programme for gifted ones and this programme should be included in the curriculum. They suggest that the programme developed according to the multiple-intelligence theory should be designed specifically for the gifted ones and BEP (Individualised Education Programme) should be prepared in this sense. A sample view from one of the parents is presented below.

P13: The interest area of the gifted and talented ones is quite vast. Thus, they have their original ideas and projects in their minds. They always want to accomplish these ideas. While they try to do this, they encounter the obstacles of the curriculum designed with some certain criteria. Since curricula are generally within certain limits, they always lag behind in meeting the needs of these individuals.

In addition, it is noteworthy that a solution proposal for the environmental and peer related problems of children is not presented. However, requesting homogeneous class structures can be interpreted as a solution proposal for this problem. There are similarities as well as differences among the solution suggestions. There are parents, who demand homogenous class structures, as well as those who demand heterogeneous classes not divided by diversified class structures.

It can be said that the solutions offered by parents with gifted children are compatible with the problems experienced by the children. The parents state the problems experienced by the children and offer solution proposals for these problems.

\section{Conclusion and Discussion}

From the standpoints of the parents, it has been investigated what the problems experienced by gifted children are and what kind of solutions they offer for these problems. It is important to take into consideration in the studies and applications for gifted children, where parents convey the problems experienced by children and what solutions they offer. That the parents convey the problems experienced by children and the solutions they offer are important to be taken into consideration in the studies and applications for gifted children. Karakuş $(2010 ; 130)$ alleges that in order for the gifted children to continue their development as a whole in line with the features they have, they should benefit from learning experiences appropriate for their own levels starting from earlier ages. It is the duty of the families of these individuals, who have superior talents, to meet their educational needs, especially from an early age, and to guide them to proceed in the right areas. On the other hand, the problems faced by gifted children are also experienced and witnessed by their families with their children. For this reason, she states that the opinions of the parents are important for both the education of the gifted children and the solution of their problems. This reveals the importance of this study.

At the end of the study, it has been determined that the problems experienced by the students are caused by private institutions, educators, families, curriculum and educational environments, self- 
assessments, environmental expectations, the absence of practice of educational models, problems originating from BİLSEM, peer communication, economic problems and materials and activities. It has been determined that the children experience problems arising from the programs and curriculums regarding their education.

In the study of Karakuş (2010; 142-143) regarding the problems experienced by parents with gifted children, similarly, it has been determined that children are not guided according to their interests and abilities, and they face problems related to BILSEM. It was determined that they have problems in communicating with teachers, peers and families who do not have sufficient knowledge about gifted individuals. In addition, the socio-economic levels of the families have also been found to expose children to the problems.

Gifted children who differ from their peers in terms of educational needs and many other needs need educational programs to support their potential. (Feldhusen, 1997; Renzulli, 1999; Clark, 2002; Horn, 2002). The combination of curriculums that are not suitable for gifted children with unsuitable educational environments has been found to make it difficult for parents to direct their children according to their abilities and prevent the children's performances from emerging. In the study of Oruç, Ateş, Çağır (2019: 255), it has been stated that the education given in public schools is difficult as applied curriculum is limited and the classes are crowded.

Stating that the social environment, peers and teachers of gifted child have the expectation that the child will excel in all areas, the parents indicate that this situation both affects the child negatively and causes anxiety for the child. Davasligil (1990) states that adults' expectations from gifted children to be superior in all areas are wrong.

She points out that she had the problem of finding teachers trained specifically on gifted children and the lack of educators who are to lead children to the related fields. For this reason, parents suggest that teachers should be educated about gifted students regardless of their branches at the universities. They expect teachers to be able to satisfy gifted children, direct them correctly, and produce projects with students who are active. Therefore, they suggest equipping teachers in this direction at the university. In another study (Erişen, Yavuz Birben, Sevgi Yalın, Ocak 2015; 588), they claim that it is important to train teachers in line with the characteristics of the gifted children and to increase their level of knowledge and skills and to plan education by considering these students in their classrooms. It also supports the suggestions made by the parents.

While the parents draw attention to the lack of private institutions, it is found that the difficulty of accessing these institutions leads students to move away from these institutions and creates economic problems for parents. Işık and Güneş (2017) state that private institutions except for BİLSEM, which has the principle of equality of opportunity, are aimed at a small scale and are also limited in terms of quotas. They state that they are not common in the country in general.

It is stated by the parents that there is a need to create employment opportunities for these children, there is a lack of communication with the parents in the studies to be done for these children, and they offer as a solution that communication should be increased, trainings should be given to the parents, multiple talent areas should be addressed in the education processes since the evaluations are made only according to the results of the exams. It is stated that evaluations should be made for more than one skill area. In addition, parents want academicians to be more actively involved in studies for gifted people. The Parliamentary Research Commission Report and the Strategic Action Plan for Gifted Students (2013-2017) is consistent with the planned policies and practices in Turkey in the next years on behalf of the gifted children. According to the report, the multi-talent approach will become widespread, an intensive parent education model will be adopted in pre-school for these children and that there is a need to increase employment opportunities for 
gifted children. The biggest obstacle in the implementation of these plans is the lack of academicians working in this field (Şahin, 2015: 1219).

Parents offer different solutions for these problems. These suggestions follow as such; increasing statefunded institutions, training for educators and administrators, training for RAM (Rehabilitation and Research Centre), providing employment opportunities, preparing state policies, founding research centres at universities, providing favourable educational environments and talent areas, and evaluations by performance, regarding the BILSEM-oriented solutions and suggestions.

In educational suggestions, parents think that there should be a special study regarding the program and curriculum, considering the development of educational environments and materials. In the Gifted and Educated Commission Report (Üstün Yetenekliler ve Eğitimleri Komisyon) (1991), it is stated that normal education programs will be insufficient in terms of supporting the development of gifted individuals. It is therefore emphasized that these individuals are groups that need the development of their superior talents and differentiated programs for their own interests and abilities.

They suggest that educators should be trained in this field regardless of their branches, innovation should be made in BILSEMs, and that academics should be active in this field and there should be applications for these children at universities. In addition, they recommend that educational institutions should be increased quantitatively for gifted students by pointing out the transportation difficulties and the number of the classes in existing institutions. Işık and Güneş (2017) emphasize that the problems regarding the deficiencies in BILSEM should be solved and that it is vital to improve the programs. They point out the necessity of developing a model at proper level based on modern and traditional education models in BİLSEMs.

In addition, in order to satisfy the individual, a proposal for evaluation based on talent area and performance is presented. They also think that employment opportunities should be created for the future of the children. It is determined that they are worried that brain drain would occur if their children could not be employed. In the Gifted and Educated Commission Report (Üstün Yetenekliler ve Eğitimleri Komisyon) (1991), it is stated that there are gifted individuals who continue their training abroad as a result of the brain drain. Thus, it is mentioned that it is possible to prevent rare gifted individuals from brain drain by employing them after their special training.

Parents suggest that they should be given family educations and applications specifically planned for these families. Davasligil (1990) utters that the biggest task in the advancement of a society in civilization belongs to its gifted people. Having such a positive effect, it is of great benefit to provide these individuals with an adequate education and to raise awareness levels of their families. According to Davasligil (2004; 461), families have a significant role in the conduction of a healthy development process. As well as problematic children are raised in problematic families in general, children with healthy development are also raised in families in which there is a positive communication. Therefore, parents should be trained on how to raise a child. She supports the families' wish stating that there is a need for this education for families with gifted children who differ from their peers.

In line with the suggestions, it can be said that parents demand the state, academics, teachers, administrators and families to cooperate for their gifted children.

\section{Recommendations}

- Studies might be carried out for the problems experienced by gifted people, determined in line with the opinions of the parents in this study. 
- A study might be conducted on whether gifted students, who are stated to have peer problems in this study, have problems with their friends at schools they attend or other gifted children at BILLEM.

- Studies regarding the solutions or expectations mentioned by the parents about their children might be carried out.

- Trainings can be provided for the parents of the gifted children, and it is recommended to cooperate in the educational process of children.

- It would be beneficial to keep in touch with parents for developing improvements, practices or studies for gifted children. 


\section{REFERENCES}

Clark, B. (1997). Growing Up Gifted. Developing the Potential of Children at Home and at School. (5th. ed.) New Jersey: Merrill, an imprint of Prentice Hall.

Çağlar, A. (1990). Okulöncesi Dönemde Çocuğun Fen Eğitiminde Ailenin Yeri ve Bazı Öneriler. Yaşadıkça Eğitim 13.

Davaslıgil, Ü. (1990). Üstün Çocuklar. Yaşadıkça Eğitim 13.

Davaslıgil, Ü. (2004). Üstün Çocuklara Sahip Ailelerin Eğitim,. 1.Türkiye Üstün Yetenekliler Kongresi Üstün Yetenekli Çocuklar Seçilmiş Makaleler Kitabı. Çocuk Vakfı Yayınları. İstanbul. http://cocukuniversitesi.aydin.edu.tr/tez/makale_kitabi.pdf\#page=84 Retrieved: 19.04.2020

Erişen, Y., Yavuz Birben, F., Sevgi Yalın, H., Ocak, P. (2015). Üstün Çocukları Fark Edebilme ve Destekleme Eğitiminin Öğretmenler Üzerindeki Etkisi. Bartın Üniversitesi Ĕ̆itim Fakültesi Dergisi. 4(2). 586-602.

Feldhusen, J.F. (1997) “Educating Teachers for Work with Talented Youth". In N. Colangelo \& G.A. Davis (Eds.) Handbook of Gifted Education, 547-555

Hallahan, D. P., Kauffman, J.M. (1994). Exceptional children: introduction to special education. (6Bs). Allyn and Bacon.

Işık, A., Güneş, E. (2017). Türk Tarihinde Özel Yeteneklilerin Eğitimi: Osmanlı Enderun Mektebi. Üstün Zekalılar Eğitimi ve Yaratıcılık Dergisi ÜZEYAD. 4(3). 1-13.

Karakuş, F. (2010). Üstün Yetenekli Çocukların Anne Babalarının Karşılaştıkları Güçlükler. Mersin Üniversitesi Eğitim Fakültesi Dergisi, 6(1): 127-144.

MEB. (2007). Milli Ĕ̆itim Tebliğler Dergisi 70(2593) http://tebligler.meb.gov.tr/index.php/tuem-sayilar/ viewcategory/ 71-2007. Retrieved: 16.04 .2020

Merriam, S.B. (2013). Nitel Araştırma. (Selahattin Turan, Trans. Edit.). 3. ed. Ankara: Nobel Yayıncılık.

Oruç, Ş., Ateş, H., Çağır, S. (2019). Türk Eğitim Sisteminde Geçmişten Günümüze Üstün Yetenekliler İçin Yapılan Uygulamalar. Uluslararası Ders Kitapları ve Eğitim Materyalleri Dergisi. 2(2). 253-273.

Özbay, Y. (2013). Üstün Yetenekli Çocuklar ve Aileleri. T.C. Aile ve Sosyal Politikalar Sağlık Bakanlığı Aile ve Toplum Hizmetleri Genel Müdürlüğü. Retrieved: 12.04 .2020 http://www.aep.gov.tr/wpcontent/uploads/2012/10/UstunYetenekliCocuklar.pdf

Patton, M. Q. (1987). How to Use Qualitative Methods in Evaluation. Newbury Park, CA: Sage.

Şahin, F. (2015). Educational Programs, Services and Support for Gifted Students in Turkey. Journal of Theory and Practice in Education. 11(4). 1207-1223

Üstün Yetenekliler ve Eğitimleri Komisyon Raporu (1991), Üstün Yetenekli Çocuklar Seçilmiş Makaleler Kitabı (2004). Çocuk Vakfı Yayınları. İstanbul. http://cocukuniversitesi.aydin.edu.tr/tez/makale_kitabi.pdf \#page = 84 Retrieved: 19.04 .2020

Yıldırım, A. and Şimşek, H. (2016). Sosyal Bilimlerde Nitel Araştırma Yöntemleri (11. ed). Ankara: Seçkin Yayıncilık 